\title{
Microbial populations, fermentative profile and chemical composition of signalgrass silages at different regrowth ages ${ }^{1}$
}

\author{
Edson Mauro Santos ${ }^{2}$, Odilon Gomes Pereira ${ }^{3}$, Rasmo Garcia ${ }^{3}$, Celia Lucia de Luces Fortes \\ Ferreira $^{4}$, Juliana Silva de Oliveira ${ }^{2}$, Thiago Carvalho da Silva ${ }^{3}$, Lilian Oliveira Rosa ${ }^{3}$ \\ ${ }^{1}$ Conselho Nacional de Desenvolvimento Científico e Tecnológico (CNPq). \\ 2 Universidade Federal da Paraíba - Centro de Ciências Agrárias - Departamento de Zootecnia. Campus II, Areia, PB - 58397-000. \\ ${ }^{3}$ Departamento de Zootecnia - Universidade Federal de Viçosa, Viçosa, MG. \\ ${ }^{4}$ Departamento de Tecnologia de Alimentos - Universidade Federal de Viçosa, Viçosa, MG.
}

\begin{abstract}
Microbial populations, $\mathrm{pH}$, ammonium nitrogen/total nitrogen $\left(\mathrm{N}_{-} \mathrm{NH}_{3}\right)$ ratio, concentrations of lactic acid, acetic acid and butyric acid and the chemical composition of Brachiaria decumbens cv. Basiliski silages at different regrowth ages (30, 40, 50, 60 and 70 days) were evaluated by using 2-kg capacity laboratory silos. It was used a $5 \times 6$ factorial scheme (5 regrowth ages $\times 6$ fermentation periods) in a complete random design, with three replicates. The fermentation periods were 1, 3, 7, 14, 28 and 56 days. Lactic acid bacteria populations were recorded in fresh forage varying from 3.93 (30 days of regrowth) to 5.51 (70 days of regrowth) log colony-forming units (cfu)/g forage. Maximum populations of these microorganisms were recorded in the silages on the seventh day of fermentation (8.69 log cfu/g silage). Enterobacteria populations persisted until the $28^{\text {th }}$ day, with maximum values found as early as the first day of fermentation ( 7.89 log cfu/g silage). Levels of DM, NDF, ADF and ADIN increased linearly whereas values of CP decreased linearly with age of regrowth of the plants. There was a linear reduction in the levels of DM, CP and NDF and linear increase in the levels of ADIN over the period of fermentation. $\mathrm{N}_{-} \mathrm{NH}_{3}$ level decreased and increased linearly with regrowth age and fermentation period, respectively. The $\mathrm{pH}$ decreased exponentially with fermentation period. Lactic acid increased and butyric acid decreased linearly with regrowth age. The predominant Lactobacillus plantarum species in signalgrass plants is Lactobacillus plantarum.
\end{abstract}

Key Words: acetic acid, butyric acid, enterobacteria, lactic acid, lactic acid bacteria

\section{Populações microbianas, perfil fermentativo e composição bromatológica de silagens de capim-braquiária em diferentes idades de rebrotação}

\begin{abstract}
RESUMO - Foram avaliadas as populações microbianas, o pH, a relação nitrogênio amoniacal/nitrogênio total $\left(\mathrm{N}-\mathrm{NH}_{3}\right)$, as concentrações de ácidos láctico, acético e butírico e a composição bromatológica de silagens de Brachiaria decumbens cv. Basiliski de cinco idades de rebrotação (30, 40, 50, 60 e 70 dias) utilizando-se silos laboratoriais de 2 kg de capacidade. Utilizou-se um esquema fatorial $5 \times 6$ (5 idades de rebrotação $\times 6$ períodos de fermentação), em um delineamento inteiramente casualizado, com três repetições. Os períodos de fermentação foram 1, 3, 7, 14, 28 e 56 dias. Na forragem fresca, foram registradas populações de bactérias do ácido láctico variando entre 3,93 (30 dias de rebrotação) e 5,51 (70 dias de rebrotação) log unidades formadoras de colônia (ufc)/g de forragem. Nas silagens, foram registradas populações máximas desses microrganismos no sétimo dia de fermentação (8,69 log ufc/g de silagem). As populações de enterobactérias persistiram até o 28 o dia, com os valores máximos observados logo no primeiro dia de fermentação (7,89 log ufc/g de silagem). Os teores de MS, FDN, FDA e NIDA aumentaram linearmente, enquanto os de PB diminuíram linearmente com a idade de rebrotação das plantas. Houve redução linear dos teores de MS, PB e FDN e aumento linear dos teores de NIDA com o avanço do período fermentativo. O teor de $\mathrm{N}-\mathrm{NH}_{3}$ decresceu e aumentou linearmente com a idade de rebrotação e com o período de fermentação, respectivamente. O pH decresceu exponencialmente com o período de fermentação. Os teores de ácido láctico aumentaram e os de ácido butírico decresceram linearmente com a idade de rebrotação. A espécie de Lactobacillus predominante em plantas de capim-braquiária é o Lactobacillus plantarum.
\end{abstract}

Palavras-chave: ácido acético, ácido butírico, ácido láctico, bactérias do ácido láctico, enterobactérias

\section{Introduction}

The potential of a plant for silage depends on its original level of humidity, which should be close to $70 \%$ of the soluble carbohydrate content (above $8 \%$ in the DM), and of the low buffer power, which should offer no resistance to the reduction of the $\mathrm{pH}$ to values from 3.8 to 4.0 (McDonald et al. 1991). During the ensiling process, 
the development and predominance of groups of microorganisms take place at different stages of this process following a succession of microorganisms that are directly related to the $\mathrm{O}_{2}$ concentration and the medium pH (Meeske et al., 1999).

Grasses are colonized by a large numbers of lactic acid bacteria. In most cases, different species occur simultaneously in the same culture (Daeschel et al., 1987). According to Pahlow et al. (2003), in a review paper, the most commonly species found in plants are the Lactobacillus plantarum, Lactobacillus casei, Pediococcus acidilactici and Enterococcus faecium. Some heterofermentative lactic acid bacteria may also be found in such medium.

Lactic acid bacteria (LAB) of the autochthonous microbial populations are essential for the fermentation of the silage. However, no group varies in number as this one, going from the limit of detection $10^{1}$ to $10^{5} \mathrm{cfu} / \mathrm{g}$ forage in alfafa, $10^{6} \mathrm{cfu} / \mathrm{g}$ forage in perennial grasses and $10^{7} \mathrm{cfu} / \mathrm{g}$ forage in corn and sorghum (Pahlow et al., 2003).

The harvest of the forage must be related to the development stage, therefore to its nutritive value. More mature forages present low digestibility indirectly because of the decreases in leaf/stem ratio. Moreover, in general, grasses have low dry matter (DM) content, low populations of lactic acid bacteria, high buffering capacity, and reduced amount of soluble carbohydrates, when their nutritional value is elevated (Evangelista et al., 2004).

Information on the development of microbial populations and fermentation characteristics of tropical climate grass silage, associated with changes in their chemical composition, due to the stage of maturity is scarce in the literature concerning the topic. Thus, the objective of this study is to characterize and to quantify the microbial populations and to evaluate the fermentation characteristics and the chemical composition of silage produced from signalgrass collected at different stages of regrowth.

\section{Material and Methods}

The experiment was conducted at the Departamento de Zootecnia of Universidade Federal de Viçosa, located in Viçosa-MG, from December, 2004 to March, 2005. The city is located at $20^{\circ} 45^{\prime} \mathrm{S}$ and $42^{\circ} 51^{\prime} \mathrm{W}$ at $657 \mathrm{~m}$ altitude, with an annual average rainfall of 1,342 millimeters, of which about 86\% occur from October to March.

For this experiment, it was used a signalgrass pasture (Brachiaria decumbens cv. Basiliski), implemented 10 years ago in an area where the soil is classified as Red-Yellow Ultisol, with a clay loam texture. It was applied $500 \mathrm{~kg} / \mathrm{ha}$ of dolomitic limestone PRNT $83 \%$ on November $2^{\text {nd }} 2004$, to raise the base saturation to $60 \%$.

The pasture was divided into plots of $30 \mathrm{~m}^{2}$ for each regrowth age. The first plot was cut for uniformity on November $20^{\text {th }} 2004$. The other ones were cut at 10-day intervals, from the highest to lowest regrowth age, to collect and to ensilage grasses of all regrowth ages in a single day. The plants were cut at $10 \mathrm{~cm}$ from the ground and, after the cutting of each plot, $250 \mathrm{~kg} / \mathrm{ha}$ of 20-5-20 fertilizer were applied.

The isolation of lactobacilli predominant in the grass before ensiling was done through the growth in Rogosa Agar (Difco) culture medium, at $37^{\circ} \mathrm{C}$ for 48 hours. Samples were collected randomly from the grass at $30,40,50,60$, and 70 days of regrowth. After that, it was formulated a composed sample, which was immediately taken to the laboratory for analysis. In an industrial blender, $10 \mathrm{~g}$ of grass and $90 \mathrm{~mL}$ of phosphate buffer sterile solution was crushed for one minute, resulting in a dilution of $10^{-1}$. Then, serial dilutions were performed, ranging from $10^{-1}$ to $10^{-6}$ and the duplicate plating in sterile petri dishes. From the higher elevated dilutions, a number of colonies were selected, equivalent to the square root of the total of colony-forming units (cfu), observed in the plates. This procedure was performed to select the predominant strains in the medium.

The colonies were selected from the dilution $10^{-3}$. Due to the counts on the plates of $40 \mathrm{cfu}$, six colonies were selected to each plate, resulting in twelve colonies, which were grown in MRS broth (De Man et al., 1960) at $37^{\circ} \mathrm{C}$ for 48 hours. Later, two isolations were performed in simple stretches on solid medium for separation, and, consequently, for purification of isolated cultures. The tests of gram coloration and of reaction to the enzyme catalase were performed, and six gram-positive cultures, shaped as bacilli and negative catalase were again grown in MRS broth for further tests of identification and characterization.

The identification of the isolated items was performed through the fermentation of the carbohydrates in an API CH 50 kit (BioMeurix - France). Four pure cultures of signalgrass, with similar morphology, negative and grampositive catalase were submitted to three successive activations, being the last one made in a $20-\mathrm{mL}$ volume. Afterwards, each culture was centrifuged in polypropylene centrifuge tubes with screw caps previously sterilized.

After discarding the supernatant, the cell concentrates were re-suspended to $5 \mathrm{~mL}$ of sterile phosphate buffer ( $\mathrm{pH}=7.2)$, for washing the cells. Then, a further centrifugation was made. Afterwards, the supernatant was discarded and re-suspended again in $2 \mathrm{~mL}$ of phosphate buffer. 
The standardization of the inoculums was performed by adding drops of the initial inoculums in $5 \mathrm{~mL}$ of distilled water, in order to get an optical density of $0.70 \pm 0.2$ on a spectrophotometer at $550 \mathrm{~nm}$. A double dosage of drops was added in $10 \mathrm{~mL}$ of CHL medium (modified MRS, with no addition of meat extract and glucose, and supplemented with purple bromocresol).

The bacterial suspension in a CHL medium was distributed in the domes of the tray, with a further cover with mineral oil, in order to maintain the anaerobiosis. The trays were incubated at $37^{\circ} \mathrm{C}$ in a BOD incubator. The reading of each isolated item, by means of change in coloration from blue to yellow, was done at 24 and 48 hours. The identification was performed by the API software (BioMeurix - France), expressing the result as a percentage of identification.

Growing tests of the isolated items were conducted in concentrations of salt, $\mathrm{pH} 9.6$ and at temperatures of 15 and $45^{\circ} \mathrm{C}$. Tryptic Soy Broth (TSB) adjusted to $\mathrm{pH} 7.2$ was used for the growing tests at 4.0 and $6.5 \%$ of $\mathrm{NaCl}$ in $\mathrm{pH} 7.2$ and 9.6. The cultures were incubated in a TSB medium at $\mathrm{pH} 7.2$ without addition of $\mathrm{NaCl}$, and in media with $\mathrm{NaCl}$ at $\mathrm{pH} 9.6$ concentrations. The isolated items were also incubated at $15^{\circ} \mathrm{C}$ and at $45^{\circ} \mathrm{C}$ in MRS broth. After 24 hours of incubation, it was observed by the turbidity of the media whether there was growth in the different conditions which were imposed on those cultures.

The grass destined to the silage was harvested at 30, 40, 50,60 , and 70 days of regrowth, $10 \mathrm{~cm}$ above ground, with the aid of a cutter cage, and then processed in a stationary chopper. Soon after, silage was performed in PVC silos $(10 \mathrm{~cm} \times 50 \mathrm{~cm})$, equipped with a bünsen valve for the escapement of gases. The compaction of the material was performed with sockets of wood, putting approximately $2 \mathrm{~kg}$ of fresh forage per silo.

It was used a $5 \times 6$ factorial scheme $(5$ regrowth ages $\times 6$ periods of fermentation) in a randomized design with three replicates. The fermentation periods evaluated were $1,3,7$, 14, 28, and 56 days.
Microbial populations were quantified through the use of selective culture media to each group: Rogosa Agar (Difco) for the enumeration of lactic acid bacteria and Violet Red Bile (Difco) for the enumeration of enterobacteriaceae.

The counting of the microbial groups was performed from $10 \mathrm{~g}$ of a sample of silage from three silos of each treatment in different periods of fermentation, to which it was added $90 \mathrm{~mL}$ of phosphate buffer solution, and crushed in an industrial blender for one minute, resulting in a dilution of $10^{-1}$. Then, successive dilutions were performed, aiming to obtain dilutions ranging from $10^{-1}$ to $10^{-9}$, being the plates considered likely of counting when the values are between 30 and 300 colonies.

In each open period, $25 \mathrm{~g}$ of silage were taken, to which $100 \mathrm{~mL}$ of water was added, resting for one hour for the reading of $\mathrm{pH}$ by using a potentiometer. In $200 \mathrm{~mL}$ of $\mathrm{H}_{2} \mathrm{SO}_{4}$ solution, it was placed $25 \mathrm{~g}$ of silage, remaining in rest in a refrigerator for 48 hours; after filtration through paper filter, the filtrated content was frozen for later determination of ammonia nitrogen, according to Bolsen et al. (1992).

Approximately $500 \mathrm{~g}$ of silage sample were collected from each silo and plants before the ensiling process. These samples were previously oven-dried $\left(65^{\circ} \mathrm{C}\right)$ and analyzed fot the contents of dry matter (DM), soluble carbohydrates (CHO), crude protein (CP), neutral detergent fiber (NDF), acid detergent fiber (ADF), and acid detergent insoluble nitrogen (ADIN) were performed. Dry matter was determined by means of drying in an oven at $105^{\circ} \mathrm{C}$ for 24 hours. Soluble carbohydrates (CHO) were determined according to Deriaz (1961), CP by Kjeldahl's method, NDF and ADF by the autoclave method described by Pell and Schofield (1993) and INDA in accordance to Van Soest and Robertson (1985). The percentage of DM, NDF, ADF, and INDA increased with the raising of the regrowth age, while the $\mathrm{CP}$ concentration decreased (Table 1).

For the determination of the organic acids, approximately $25 \mathrm{~g}$ of fresh silage were diluted in $250 \mathrm{~mL}$ of distilled

Table 1 - Dry matter (DM), solubhe carbohydrates (CHO), crude protein (CP) and fiber of signalgrass (Brachiaria decumbens cv. Basiliski) at different regrowth ages

\begin{tabular}{lcccc}
\hline & \multicolumn{3}{c}{ Plant age (days) } \\
\cline { 2 - 5 } & 30 & 40 & 50 & 60 \\
Dry matter (\%) & 21.25 & 22.65 & 22.71 & 22.90 \\
Soluble carbohydrates (\% DM) & 2.95 & 3.51 & 3.40 & 3.31 \\
Crude protein (\% DM) & 9.71 & 7.13 & 5.71 & 25.64 \\
Neutral detergent fiber (\% DM) & 65.81 & 68.75 & 70.42 & 71.41 \\
Acid detergent fiber (\% DM) & 34.80 & 36.20 & 38.71 & 42.51 \\
Insoluble in acid detegent nitrogen (\% total N) & 5.10 & 5.21 & 7.52 & 8.35 \\
\hline
\end{tabular}


water and homogenized in an industrial blender for one minute. The resulting aqueous extract was filtered through paper filter, and $100 \mathrm{~mL}$ were acidified with $\mathrm{H}_{2} \mathrm{SO}_{4} 50 \%$ and filtered in quick filtering paper (Ranjit \& Kung Jr., 2000). In $2 \mathrm{~mL}$ of the filtrated solution, it was added $1 \mathrm{~mL}$ of $20 \%$ metaphosphoric acid and $0.2 \mathrm{~mL}$ of $1 \%$ carbolic acid, used as an internal pattern. The determination of lactic acid, acetic acid and butyric acid was performed by highperformance liquid chromatography (HPLC), Schimadzu SPD-10 trademark, with a wavelength of $210 \mathrm{~nm}$. It was used a C-18 column, of reverse phase, with $168 \mathrm{kgf}$ pression at $1.5 \mathrm{~mL} / \mathrm{min}$.

The data related to the chemical constituents and to the obtained organic acids were submitted to analysis of variance and regression by using the program SAEG, version 8.0. The choice of regression equations was based on the coefficient of determination and on the significance of regression coefficients by using the $t$ test at the level 5\% of significance. For evaluating the $\mathrm{pH}$, according to the fermentation period, it was done an adjustment of the data to the non-linear model: $Y t=A+B \times e^{-c t}$, proposed by Hristov \& McAllister (2002). The values of the chemical constituents, $\mathrm{N}-\mathrm{NH}_{3}$, and of the lactic, acetic, and butyric acids were adjusted to the response surface model with two independent variables (regrowth ages and the fermentation period).

\section{Results and Discussion}

Concerning the identification of the predominant bacteria in signalgrass plants, all isolated items presented the shape of short bacilli with rounded extremities, arranged in pairs or in short chains (3-4 cells; Table 2). All the items were gram-positive and reacted negatively to the test catalase enzyme. None of the isolated items grew at pH 9.6 and $6.5 \%$ $\mathrm{NaCl}$, but all of them grew at $\mathrm{pH} 7.2$ and $4 \% \mathrm{NaCl}$ at $45^{\circ} \mathrm{C}$ temperature.

According to the profile of fermentation of carbohydrates (Table 3), the isolated EB1, EB2, EB5, and EB6 were identified as Lactobacillus plantarum, with $99.9 \%$ of similarity.

L. plantarum, identified as dominant among signalgrass plant, was isolated and characterized as a main specie among different cultures. Lin et al. (1992), when evaluating the autochthonous microbiota of corn and alfalfa, found that from the total isolated lactic acid bacteria, 90\% were homofermentative lactic acid bacteria, being L plantarum the predominant specie. Tjandraatmadja et al. (1994), on studies with silages produced from three tropical grasses, highlighted the L. plantarum and Pediococcus spp. as predominant species.

In another study, Pereira et al. (2007) assessing the population of lactic bacteria of elephant grass cv. Cameroon (Pennisetum purpureum Schum), identified the isolated items as Lactobacillus casei ssp pseudoplantarum by using the profile of fermentation of carbohydrates as a criterion for identification. As reported above, there is a difference in the dominant specie of lactic acid bacteria among the cultures evaluated.

The couting of LAB ranged from 3.93 to $5.51 \mathrm{log} \mathrm{cfu} / \mathrm{g}$ for plants harvested between 30 and 70 days of regrowth (Table 4). It was registered, in the silages, populations of these maxims microorganisms on the seventh day of fermentation (8.90 log cfu/g silage), regardless of the regrowth age.

Table 2 - Morfology and biochemistry characteristics of strains EB1, EB2, EB3, EB4, EB5, EB6 isolated from signalgrass (Brachiaria decumbens cv. Basiliski) plants

\begin{tabular}{|c|c|c|c|c|c|c|c|}
\hline & \multicolumn{6}{|c|}{ Isolated strain } & \multirow[b]{2}{*}{ L. plantarum } \\
\hline & EB1 & EB2 & EB3 & EB4 & EB5 & EB6 & \\
\hline Shape & Rod & Rod & Rod & Rod & Rod & Rod & Rod \\
\hline Arrangement & $\mathrm{DB} *$ & DB & DB & DB & DB & DB & DB \\
\hline Gram & + & + & + & + & + & + & + \\
\hline Catalasis & - & - & - & - & - & - & - \\
\hline \multicolumn{8}{|c|}{ Growth at different $\mathrm{pH}$} \\
\hline 7.2 & + & + & + & + & + & + & + \\
\hline 9.6 & - & - & - & - & - & - & - \\
\hline \multicolumn{8}{|c|}{ Growth at different salt concentration ( $\mathrm{NaCl})$} \\
\hline $\mathrm{NaCl}(4 \%)$ & + & + & + & + & + & + & + \\
\hline $\mathrm{NaCl}(6.5 \%)$ & - & - & - & - & - & - & - \\
\hline \multicolumn{8}{|c|}{ Growth at different temperatures $\left(\mathrm{T}^{\circ} \mathrm{C}\right)$} \\
\hline $15^{\circ} \mathrm{C}$ & + & + & + & + & + & + & + \\
\hline $45^{\circ} \mathrm{C}$ & + & + & + & + & + & + & + \\
\hline
\end{tabular}

*DB - diplobacilli. 
Table 3 - Fermentation profile of carbohydrates of isolated EB1, EB2, EB5 e EB6 of signalgrass (Brachiaria decumbens cv. Basiliski) plants

\begin{tabular}{|c|c|c|c|c|c|}
\hline & \multicolumn{4}{|c|}{ Isolated strain } & \multirow[t]{2}{*}{ L. plantarum } \\
\hline & EB1 & EB2 & EB5 & EB6 & \\
\hline Glycerol & - & - & - & - & - \\
\hline Erythritol & $(+)$ & $(+)$ & $(+)$ & $(+)$ & - \\
\hline D-arabinose & - & - & - & - & - \\
\hline L-arabinose & + & + & + & + & + \\
\hline Ribose & + & + & + & + & + \\
\hline D-xylose & - & - & - & - & - \\
\hline L-xylose & - & - & - & - & - \\
\hline Adonitol & - & - & - & - & - \\
\hline$\beta$-methyl D-xyloside & - & - & - & - & - \\
\hline Galactose & + & + & + & + & + \\
\hline D-glucose & + & + & + & + & + \\
\hline D-frutose & + & + & + & + & + \\
\hline D-mannose & + & + & + & + & + \\
\hline L-sorbose & - & - & - & + & - \\
\hline Rhamnose & $(+)$ & $(+)$ & $(+)$ & $(+)$ & - \\
\hline Dulcitol & - & - & - & - & - \\
\hline Inositol & - & - & - & - & - \\
\hline Mannitol & + & + & + & + & + \\
\hline Sorbitol & + & + & + & + & + \\
\hline$\alpha$-methyl D-mannose & - & - & - & - & + \\
\hline$\alpha$-methyl D-glycoside & - & - & - & - & - \\
\hline N-acetyl-glucosamine & + & + & + & + & + \\
\hline Amygdaline & + & + & + & + & + \\
\hline Arbulin & + & + & + & + & + \\
\hline Esculin & + & + & + & + & + \\
\hline Salicin & + & + & + & + & + \\
\hline Cellobiose & + & + & + & + & + \\
\hline Maltose & + & + & + & + & + \\
\hline Lactose & + & + & + & + & + \\
\hline Melibiose & + & + & + & + & + \\
\hline Saccharose & + & + & + & + & + \\
\hline Trehalose & + & + & + & + & + \\
\hline Inulin & - & - & - & - & - \\
\hline Melezitose & + & + & + & + & + \\
\hline D-raffinose & + & + & + & + & + \\
\hline Amidon & - & - & - & - & - \\
\hline Glycogene & - & - & - & - & - \\
\hline Xylitol & - & - & - & - & - \\
\hline$\beta$-gentibiose & + & + & + & + & + \\
\hline D-turanose & + & + & + & + & + \\
\hline L-lyxose & - & - & - & - & - \\
\hline D-tagatose & - & - & - & - & - \\
\hline D-fucose & - & - & - & - & - \\
\hline L-fucose & - & - & - & - & - \\
\hline D-arabitol & $(+)$ & $(+)$ & $(+)$ & $(+)$ & - \\
\hline L-arabitol & - & - & - & - & - \\
\hline Gluconate & + & + & + & + & + \\
\hline 2Cetogluconate & - & - & - & - & - \\
\hline 5Cetogluconate & - & - & - & - & - \\
\hline
\end{tabular}

Enterobacter populations reached maximum values on the very first day after the ensiling process, declining from this point. It was not detected its presence in the last period of fermentation. This microbial group decreased with the increasing of the regrowth age during the entire fermentation period.

Plants harvested at 30 and 40 days of age did not reach counts of $5 \log \mathrm{cfu} / \mathrm{g}$, established by Muck (1996) as the minimum necessary for losses being minimal during the fermentation process. However, it is interesting to highlight the rapid and significant increase in the $\mathrm{LAB}$ earlier in the fermentation period. Perhaps, the cutting and later ensiling release catalase enzymes and superoxide dismutase from the plants, stimulating the growth of lactic acid bacteria, promoting a marked increase, even before the anaerobic conditions were established in silos (Pahlow, 2003).

It is important to highlight that the silages produced from more advanced age plants present a higher LAB population than the ones produced from younger plants. According to Knicky (2005), this can be attributed to the increased soluble carbohydrate content, of dry mass, as well as the reduction of anionic substances, such as salts of organic acids, nitrate, sulfate, among others. Pereira et al. (2005) also reported an increase in the LAB population in elephant grass in accordance with the increase in the regrowth age.

The decrease in the enterobacteria population from the first day of fermentation in the different silages can be attributed to the rapid drop of the $\mathrm{pH}$ level. The reduction in the population of these microorganisms in silages reflects the favorable potential for silage, including the availability of nutrients and water, efficient conversion of these nutrients in products of the fermentation and low $\mathrm{pH}$ level by the LABs, and, also, moderate temperatures (Pahlow et al., 2003).

According to Luis \& Ramirez (1988), the enterobacteria normally multiply until the seventh day of fermentation, approximately, when they are replaced by the lactic groups. However, these microorganisms have a great power of survival and can be found until the $30^{\text {th }}$ day of storage, due to their ability of growing under anaerobic conditions and of protecting themselves when adverse conditions are found, such as when the $\mathrm{pH}$ is very low.

Meeske et al. (1999) found in silage produced from Digitaria eriantha, that the enterobacteria population reached a peak in the first twenty-four hours of fermentation (7.1 log cfu/g), the same behavior observed in this study, decreasing to $4.6 \mathrm{log} \mathrm{cfu} / \mathrm{g}$ on day seven of fermentation.

By evaluating the microbial populations in silages produced from elephant grass, harvested at $10,11,12$, and 13 weeks of regrowth, Pereira et al. (2005) found that the populations of enterobacteriaceae reached values close to $6 \log \mathrm{cfu} / \mathrm{g}$ for the four regrowth ages, and did not find any occurrence of this microbial group after the seventh day of ensilage for all the silages.

It is interesting to highlight that fluctuations in microbial populations follow the behavior of variation of $\mathrm{pH}$ level 
(Figure 1) and soluble carbohydrates (Table 5), observing an increasing in LAB populations and a declining in ENT populations, with the $\mathrm{pH}$ reduction of the silages.

It is possible to verify a rapid fall of $\mathrm{pH}$ level on the first day of fermentation, and a stabilization of $\mathrm{pH}$ from the seventh day on. It was expected reductions of $\mathrm{pH}$ of 0.87 ; $0.92 ; 0.92 ; 0.92 ; 0.92$ units per day of fermentation for silage harvested at $30,40,50,60$, and 70 days of regrowth, respectively.

Concerning the concentration of $\mathrm{N}-\mathrm{NH}_{3}$, there was a linear reduction $(\mathrm{P}<0.05)$ and increase $(\mathrm{P}<0.05)$ according to the age of regrowth and the fermentation period, respectively. It was estimated values of $\mathrm{N}-\mathrm{NH}_{3}$ at the end of period of fermentation, ranging from $22.49 \%$ total $\mathrm{N}$
(30 days of regrowth) to $10.21 \%$ total $\mathrm{N}$ (70 days of regrowth). The $\mathrm{CHO}$ content was influenced in a quadratic way $(\mathrm{P}<0.05)$ by the age of regrowth and by the period of fermentation.

There was a linear increase $(\mathrm{P}<0.05)$ of the lactic acid content with the regrowth age and period of fermentation, expecting values of 2.22 and 3.93\% DM, for the lowest and for highest age of regrowth, respectively, at the end of the fermentation period. Moreover, the levels of acetic and butyric acid decreased $(\mathrm{P}<0.05)$ with the advanced age of regrowth and increased linearly $(\mathrm{P}<0.05)$, with the period of fermentation.

Lactic bacteria use soluble carbohydrates to produce lactic acid and to the consequent lowering of $\mathrm{pH}$ level

Table 4 - Count of lactic acid bacteria and enterobacter in signalgrass (Brachiaria decumbens cv. Basiliski) silages at different regrowth ages during fermentation

\begin{tabular}{|c|c|c|c|c|c|c|c|}
\hline \multirow[b]{2}{*}{ Plant age (days) } & \multicolumn{7}{|c|}{ Fermentation period (days) } \\
\hline & $0^{1}$ & 1 & 3 & 7 & 14 & 28 & 56 \\
\hline & \multicolumn{7}{|c|}{ Lactic acid bacteria (log ufc/g) } \\
\hline 30 & 3.93 & 6.60 & 6.43 & 7.99 & 7.99 & 7.81 & 5.54 \\
\hline 40 & 4.81 & 6.84 & 7.57 & 8.25 & 8.25 & 8.22 & 6.15 \\
\hline 50 & 5.37 & 6.20 & 7.81 & 8.69 & 8.39 & 8.31 & 6.51 \\
\hline 60 & 5.32 & 7.85 & 8.03 & 8.75 & 8.45 & 8.40 & 7.21 \\
\hline 70 & 5.51 & 7.82 & 8.53 & 8.90 & 8.79 & 7.71 & 6.69 \\
\hline \multicolumn{8}{|c|}{ Enterobacter (log ufc/g) } \\
\hline 30 & 7.68 & 7.84 & 7.85 & 6.79 & 5.76 & 4.54 & Not detected \\
\hline 40 & 7.55 & 6.84 & 6.56 & 6.70 & 4.70 & 4.47 & Not detected \\
\hline 50 & 7.49 & 7.22 & 6.38 & 4.63 & 4.49 & 3.32 & Not detected \\
\hline 60 & 7.53 & 7.83 & 6.34 & 4.57 & 4.49 & 3.25 & Not detected \\
\hline 70 & 7.08 & 7.89 & 6.23 & 4.55 & 4.21 & 3.20 & Not detected \\
\hline
\end{tabular}

${ }^{1}$ Plant before ensilage.

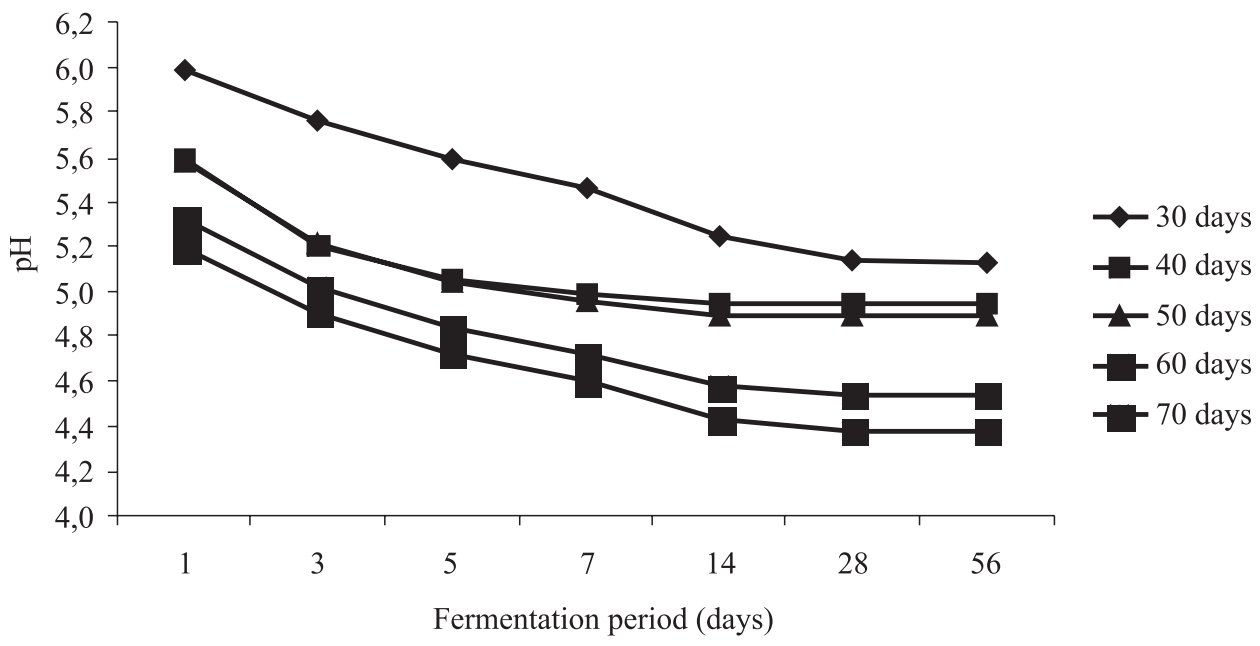

$\begin{array}{ll}{ }^{1} \hat{Y}=5.1273+0.8756 \mathrm{e}^{-0.8700 * \mathrm{P}} & \mathrm{r}^{2}=0.9210 \\ { }^{2} \hat{\mathrm{Y}}=4.9487+0.6618 \mathrm{e}^{-0.9200 * \mathrm{P}} & \mathrm{r}^{2}=0.7390 \\ { }^{3} \hat{\mathrm{Y}}=4.8872+0.7099 \mathrm{e}^{-0.9200 * \mathrm{P}} & \mathrm{r}^{2}=0.8440 \\ { }^{4} \hat{\mathrm{Y}}=4.5436+0.7960 \mathrm{e}^{-0.9200 * \mathrm{P}} & \mathrm{r}^{2}=0.9280 \\ { }^{5} \hat{\mathrm{Y}}=4.3802+0.8228 \mathrm{e}^{-0.9200 * \mathrm{P}} & \mathrm{r}^{2}=0.8260\end{array}$

Figure 1 - Estimative of $\mathrm{pH}$ of signalgrass Brachiaria decumbens (cv. Basiliski) silages at different regrowth ages as a function of fermentation period. 
Table 5 - Average contents of soluble carbohydrate, ammonium nitrogen $\left(\mathrm{N}-\mathrm{NH}_{3}\right)$ and lactic, acetic and butyric acids of signalgrass (Brachiaria decumbens cv. Basiliski) silages as a function of regrowth (X) age and fermentation period (Z)

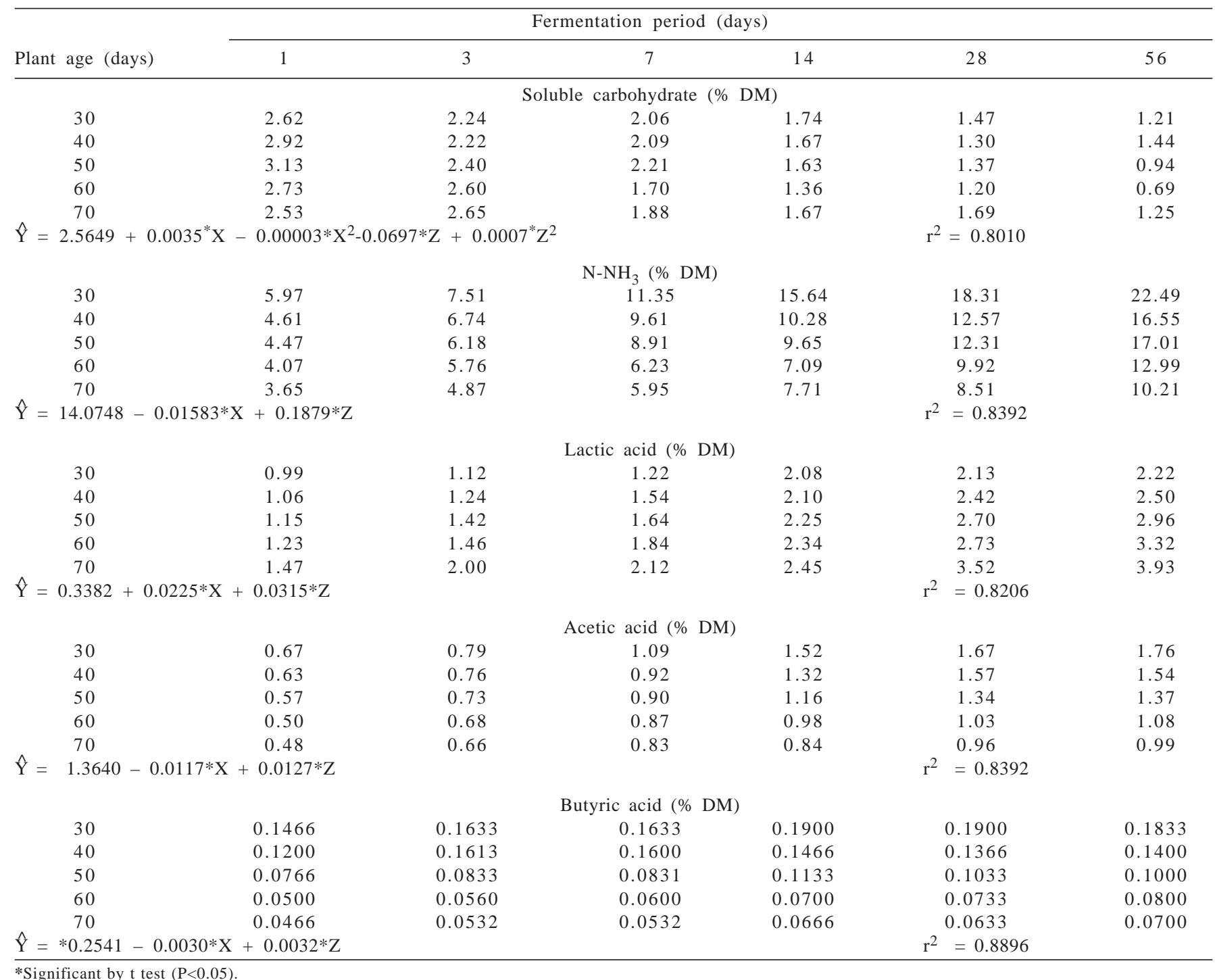

*Significant by $\mathrm{t}$ test $(\mathrm{P}<0.05)$.

(Muck, 1996). The increase in the levels of carbohydrates and dry mass, in accordance to the progress of the age of regrowth may have promoted the development of lactic acid bacteria, resulting in lower levels of $\mathrm{pH}$ (Figure 1).

The rates of decline in $\mathrm{pH}$ levels silage produced from signalgrass are lower than those reported by Pereira et al. (2005), who anticipated rates of decline of 0.0793 , $0.0757,0.0782$, and $0.0656 \% / \mathrm{h}$ in a silage produced from elephant grass harvested at $10,11,12$, and 13 weeks of regrowth, respectively. This can be attributed to the higher soluble carbohydrate content, to the dry mass content, and to the LAB population of elephant grass.

The reduction in the concentration of ammoniacal nitrogen, related to the age of regrowth, may have been caused by the decrease of the enterobacteria, as demonstrated in this study, or by the reduction of clostridium bacteria, considering that they thrive best in silages with higher pH level (McDonald et al., 1991).

The increase of 0.0225 units per day of regrowth in lactic acid content can be attributed to the higher content of DM and soluble carbohydrates, as well as to the LAB population of plants harvested at more advanced ages of regrowth, as suggested by Muck (1996). This fact may have contributed to the reduction of the levels of acetic and butyric acids with the increase in the age of regrowth. It is added to this the reduction in the enterobacteria population according to the age of regrowth.

Dry matter linearly increased and decreased $(\mathrm{P}<0.05)$ according to the age of regrowth and to the fermentation period, respectively (Table 6). At the end of the fermentation period, DM values ranged from 19.40 to $23.75 \%$, from the lowest to the highest age of regrowth. 
Table 6 - Average contents of dry matter (DM), crude protein (CP), fiber and acid detegente insoluble nitrogen (ADIN) of signalgrass as a function of regrowth $(\mathrm{X})$ age and fermentation period $(\mathrm{Z})$

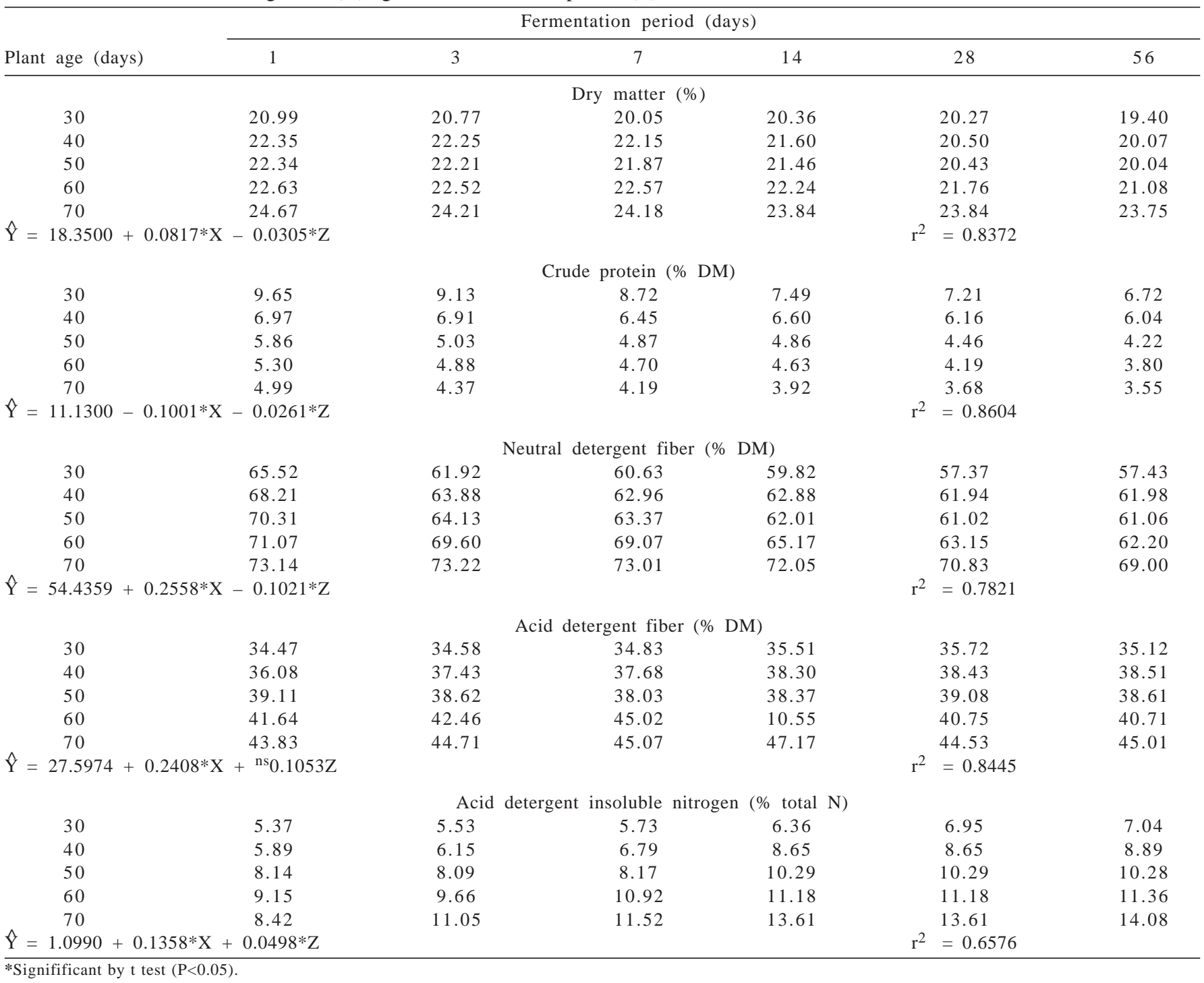

Crude protein contetns decreased linearly $(\mathrm{P}<0.05)$ according to the age of regrowth and the fermentation period, while the levels of NDF increased linearly $(\mathrm{P}<0.05)$ according to the age of regrowth and decreased $(\mathrm{P}<0.05)$ according to the fermentation period, as observed to the dry matter.

Values of ADF increased linearly $(\mathrm{P}<0.05)$ according to the age of regrowth, but they were not influenced by the fermentation period. On the other hand, The values of ADIN increased linearly $(\mathrm{P}<0.05)$ according to the age of regrowth and to the fermentation period. At the end of the fermentation, values of ADIN ranged from 7.04 to $14.08 \%$, from the lowest to the highest ages of regrowth.

Reduction in DM content during the fermentation period seems to be related to the loss of nutrients caused by secondary fermentations, which are inevitable during the fermentative process. However, reductions in DM content of silage produced from tropical grasses, throughout the fermentation period have been reported for elephant grass silage (Pereira et al., 2007) and for Mombaça grass silages (Penteado et al., 2007; Zanineet et al., 2006).

On the other hand, the reduction on the CP content according to the age of regrowth of plants is well documented in the literature. According to Muck (1996), the reduction of this constituent with the increasing fermentation period is caused by the proteolysis performed by the enterobacteria and clostridium bacteria.

Decrease in NDF content of silages of 0.1021 units per day of fermentation is probably due to acid hydrolysis of hemicellulose, which, in accordance to McDonald et al. (1991) is caused by the action of plant enzymes or enzymes of the microorganisms themselves. Pereira et al. (2007) also 
recorded a reduction of the NDF fraction with the period of fermentation in elephant grass silage.

The increased levels of ADIN according to the progress of the fermentation period is attributed to the heating of silage, resulting in the complexation of proteins and sugar, and, therefore, in the unavailability of nitrogen fraction for ruminants.

From those results, it is found that the better fermentation in silage with Brachiaria decumbens is obtained in those plants collected at older ages, which exhibit high levels of fiber and low levels of CP. This seems paradoxical inasmuch as it is tried to reap the greatest amount of nutrients per unit area, i.e., harvesting the plant growth stage that results in good nutritional value.

\section{Conclusions}

Based on morphological and biochemical characteristics of the microorganisms studied and carbohydrates fermentation profile, Lactobacillus plantarum is the predominant specie of LAB in signalgrass forage. Signalgrass plants, harvested from the $50^{\text {th }}$ day present appropriated BAL populations and soluble carbohydrate content to ensure the good fermentation, considering the values for the $\mathrm{pH}, \mathrm{N}-\mathrm{NH}_{3}$, and the lactic, acetic, and butyric acids. However, reduction of the protein and the increase of the fiber fraction, according to the regrowth age, result in a lower nutritional values for the silages.

\section{References}

BOLSEN, K.K.; LIN, C.; BRENT, B.E. et al. Effect of silage additives on the microbial succession and fermentation process of alfalfa and corn silages. Journal of Dairy Science, v.75, n11, p.3066-3083, 1992.

DAESCHEL, M.A.; ANDERSON, R.E.; FLEMING, H.P. Microbial ecology of fermenting plant materials. FEMS Microbiology Reviews, v.46, p.357-367, 1987.

DE MAN, J. C.; ROGOSA, M.; SHARPE, M. E. A medium for the cultivation of lactobacilli. Journal Applied Bacteriology, v.23, p.130-135, 1960.

DERIAZ, R.E. Routine analysis of carbohydrate and lignin in herbage. Journal of Science Food and Agriculture, v.12, p.150-160, 1961.

EVANGELISTA, A.R.; ABREU, J.G.; AMARAL, P.N.C. et al. Produção de silagem de capim-marandu (Brachiaria brizantha stapf cv. Marandu) com e sem emurchecimento. Ciência e Agrotecnologia, v.28, n.2, p.446-452, 2004.

HRISTOV, A.N.; McALLISTER, T.A. Effect of inoculants on wholecrop barley silage fermentation and dry matter disappearance in situ. Journal of Animal Science, v.80, p.510-516.

KNICKY, M. Possibilities to improve silage conservation. Disponível em: <http://diss-epsilon.slu.se/archive/00000834/01/ thesis_for_epsilon2.pdf.>. Acesso em: 21/11/2005.
LIN, C.; BOLSEN, B.E.; FUNG, D.Y.C. Epiphytic lactic acid bacteria succession during the pre-ensiling periods of alfafa and maize. Journal of Applied Bacteriology, v.73, p.375-387, 1992.

LUIS, L.; RAMIREZ, M. Evolución de la flora microbiana en ensilaje de king grass. Pastos y Forrajes, v.11, p. 249-253, 1988.

McDONALD, P.J.; HENDERSON, A.R.; HERON, S.J.E. The biochemistry of silage. 2.ed. Mallow: Chalcombe Publications, 1991. 340p.

MEESKE, R.; BASSON, H.M.; CRUYWAGEN, C.W. The effect of a lactic acid bacterial inoculant with enzymes on the fermentation dynamics, intake and digestibility of Digitaria eriantha silage. Animal Feed Science Technology, v.81, p.237-248, 1999.

MUCK, R. Inoculant of silage and its effects on silage quality. In: INFORMATIONAL CONFERENCE WITH DAIRY AND FORAGE INDUSTRIES. Proceedings... US Dairy forage Research, 1996. p.43-52.

PAHLOW, G.; MUCK,R.E.; DRIEHUIS, F. Microbiology of ensiling. In: SILAGE SCIENCE AND TECHNOLOGY. Madison. Proceedings... Madison: ASCSSA-SSSA, Agronomy 42, 2003. p.31-93.

PELL, A.N.; SCHOFIELD, E.L.D.P. Computerized monitoring of gas production to measure forage digestion in vitro. Journal of Dairy Science, v.76, p.1063-1073, 1993.

PENTEADO, D.C.S; SANTOS, E.M.; CARVALHO, G.G.P. Inoculação com Lactobacillus plantarum da microbiota em silagem de capim-mombaça. Archivos de Zootecnia, v.56, p.191-202, 2007.

PEREIRA, O.G.; SOUSA, L.O.; PENTEADO, C.S. Populações microbianas, pH e relação nitrogênio amoniacal/N total em silagens de capim-elefante com diferentes idades de rebrotação. In: REUNIÃO ANUAL DA SOCIEDADE BRASILEIRA DE ZOOTECNIA, 42., 2005, Goiânia. Anais... Goiânia: UFG, 2005. (CD-ROM).

PEREIRA, O.G.; ROCHA, K.D.; FERREIRA, C.L.L.F. Composição química, caracterização e quantificação da população de microrganismos em capim-elefante cv. Cameroon (Pennisetum purpureum, Schum.) e suas silagens. Revista Brasileira de Zootecnia, v.36, n.6, p.1742-1750, 2007.

RANJIT, N.K.; KUNG JR., L. The Effect of Lactobacillus buchneri, Lactobacillus plantarum, or a chemical preservative on the fermentation and aerobic stability of corn silage. Journal of Dairy Science, v.86, p.523-535, 2000.

RIBEIRO, K.G.; PEREIRA, O.G.; SOUZA, P.P.S. et al. Composição bromatológica de silagens de Brachiaria decumbens, tratadas com inoculante microbiano, em diferentes idades de corte. In: REUNIÃO ANUAL DA SOCIEDADE BRASILEIRA DE ZOotecniA, 40., 2003, Porto Alegre. Anais... Porto Alegre, 2003. (CD-ROM).

TJANDRAATMADJA, M.; NORTON, B.W.; MacRAE, I.C. Ensilage characteristics of three tropical grasses as influenced by stage of growth and addition of molasses. World Journal of Microbiology.Biotechnology, v.10, p.74-81, 1994.

UNIVERSIDADE FEDERAL DE VIÇOSA - UFV. SAEG Sistema para Análises Estatísticas, Versão 8.1. Viçosa, MG: Fundação Arthur Bernardes, 1999. 142p.

VAN SOEST, P.J.; ROBERTSON, N.J.B. Analysis of forages and fibrous food. Ithaca: Cornell University, 1985. 202p.

ZANINE, A. M.; SANTOS, E.D.; FERREIRA, D.J. et al. Efeito do farelo de trigo sobre as perdas, recuperação da matéria seca e composição bromatológica da silagem de capim mombaça. Brazilian Journal of Veterinary Research and Animal Science, v.53, n.6, p.803-809, 2006. 